\title{
EMERGENCE OF MEGA VESSELS AND THEIR INFLUENCE ON FUTURE MALAYSIAN SEAPORT EXPANSION REQUIREMENTS
}

\author{
NUR ANIS’SA ISMAIL, NURUL HAQIMIN MOHD SALLEH* AND JAGAN JEEVAN
}

School of Maritime Business and Management, University Malaysia Terengganu, 21030 Kuala Nerus, Terengganu

*Corresponding author: haqimin@umt.edu.my

\begin{abstract}
The emergence of mega vessels is not a new event in container shipping industry. Containerization has caused a spectacular growth in maritime transportation and brought significant developments to the industry, ranging from operation systems to seaport infrastructure expansion. Container vessels have gotten larger, with some having the capacity of 18,000 TEUs (Triple E Class), to cope with the demand for economies of scale (EOS). Mega vessels can influence the strategic planning of seaport operators for massive infrastructure development and investment on existing terminals at the seaports. The objective of this research is to identify and measure the requirements for seaport expansion that need to be prioritized by seaport operators to accommodate mega vessels. Additionally, this research aims to determine the challenges faced by seaport operator to meet the seaport infrastructure expansion requirements. Two mathematical methods were employed, namely Analytical Hierarchy Process (AHP) and Evidential Reasoning (ER). The results showed that the most important requirement for seaport expansion is navigation aspect followed by berth expansion, terminal, yard and gate operations. This research is expected to assist seaport operator in making a decision on prioritizing $\mathrm{t}$ requirements for expansion. Furthermore, this research aims to measure the readiness of seaports to serve mega vessels in global shipping industry in order to achieve competitive advantages.
\end{abstract}

Keywords: Mega vessel, seaport expansion, maritime transportation, Analytical Hierarchy Process (AHP), Evidential Reasoning (ER)

\section{Introduction}

The emergence of mega vessels is not a new event in container shipping industry. The current trading system involving non-bulk cargo has become the driving factor for shipping companies acquiring mega container vessels, which have grown in size at a rapid pace over the last decade. As container vessels keep getting larger, many major maritime consulting companies predicted that, in 2020, vessels of over 24000 TEU will be seen on a voyage (Jeon \& Yeo, 2017). The driving factor behind the development of mega vessels is the search for economies of scale by shipping companies (Merk, 2016). In general, Europe-Asia route is one of the important trade routes, and as a result, container seaports in Asia have undergone fast development, making them top seaports in global container shipping industry (Yoe, 2015). Asia-North Europe route was also one of the main trade routes for container vessels of more than 8000 TEU, from 2010 to 2014 (UNCTAD, 2014). The countries located along Asia-North Europe trade route, including Malaysia, Singapore, China and Taiwan, have become the main controllers of the global import and export activities. Hence, seaports in these respective regions may need to undergo expansion.

Owing to the rapid increase in vessels' size, seaports are facing the pressure to expand the infrastructure to accommodate the larger fleet. More commercial seaports need to be physically prepared to accommodate the largest vessels increasingly dominating in international trade. Seaports are feeling the pressure to cope with large volume of container arrivals at the port of destination, needing larger cranes and expanse of land space for container yard. Besides that, mega vessels also affect several segments of transport chains such as multimodal transportation system connecting seaports with hinterlands (Rodrigue et al., 2017). Nevertheless, seaports need to be ready to cope with mega vessel trend to increase their profits, sustain in the global competitiveness, as well as remain attractive in comparison with the neighbouring seaports including Singapore, Thailand, Indonesia and Brunei (OECD, 2017). 
Table 1: Statistics of container throughput in Port Klang (2005-2017)

\begin{tabular}{ccccc}
\hline YEAR & IMPORT & EXPORT & TRANSHIPMENT & TOTAL \\
\hline 2005 & $1,342,901$ & $1,276,661$ & $2,923,965$ & $5,543,527$ \\
2006 & $1,403,946$ & $1,367,625$ & $3,554,724$ & $6,326,295$ \\
2007 & $1,527,893$ & $1,474,193$ & $4,116,628$ & $7,118,714$ \\
2008 & $1,629,977$ & $1,598,544$ & $4,745,058$ & $7,973,579$ \\
2009 & $1,515,743$ & $1,478,354$ & $4,315,682$ & $7,309,779$ \\
2010 & $1,716,304$ & $1,718,845$ & $5,436,596$ & $8,871,745$ \\
2011 & $1,794,508$ & $1,720,542$ & $6,088,876$ & $9,603,926$ \\
2012 & $1,872,867$ & $1,821,995$ & $6,306,633$ & $10,001,495$ \\
2013 & $1,907,497$ & $1,860,613$ & $6,582,299$ & $10,350,409$ \\
2014 & $1,962,431$ & $1,942,773$ & $7,040,600$ & $10,945,804$ \\
2015 & $1,992,460$ & $1,962,237$ & $7,931,988$ & $11,886,685$ \\
2016 & $2,063,736$ & $2,038,527$ & $9,067,314$ & $13,169,577$ \\
2017 & $2,175,055$ & $2,161,053$ & $7,643,358$ & $11,978,466$ \\
\hline
\end{tabular}

Source: Westport (2017)

Port Klang was selected as the case study in this research for several reasons. It is ranked as the top 20 container ports in the world, it carries the status of Malaysian mega hub seaport and is the backbone for Malaysian trade system (see Table 1) and geographically, it is located by Malacca Straits. Furthermore, another justification of the selection of this mega hub as the case study was the nature of Port Klang as a hybrid seaport that is able to handle transshipment and gateway containers. The unique ability of this seaport to perform as hybrid node would create added pressure for the seaport to cope with fleet enlargement. The primary aim of this study is to identify the most important expansion requirement that must be met by the seaport operators in Port Klang to accommodate mega vessels. In addition, this study also aims to determine the level of readiness of the seaport operators in Port Klang to accommodate mega vessels in order to sustain their competitive advantages. Analytical Hierarchy Process (AHP) and Evidential Reasoning (ER) methods were employed to formalise human reasoning facing conflicts in multi-criteria decision-making (Wang et al., 2006). This generic model is capable of assisting seaport operators in identifying the most important expansion requirement and determining the readiness of seaport operators to accommodate mega vessels once they enter the seaport from the point of navigation until the gate operation.

The introduction of mega vessels has benefited the environment because they consume half the amount of fuel per container compared to older smaller vessels (UNCTAD, 2017). In using these mega vessels, there are three types of cost involved including operation cost, capital cost and voyage cost (Merk, 2016). The seaport operators and terminals will feel the biggest pressure in dealing with mega vessels (Pinder, 2016). This is because of the issue with the ability of the seaports to accommodate the mega vessels. Not all seaports are able to adapt to the changing trend toward mega vessels in a short period because to build a new infrastructure of the seaports requires a long time. Furthermore, the demand for feeder vessels cannot be neglected as they are very crucial for short distance shipping especially in this region (ECSA, 2016). This means that the seaports need to be prepared to accommodate larger vessels without neglecting feeder fleet. This study discusses issues that may be faced by the seaport operators and how they can cope with the changes in the container shipping business to remain competitive, by fulfilling the demands from different clients.

Seaports are unique whether in terms of the services provided, strategic geographical location for shipping lane, or capability to accommodate any size of vessels (Port Technology, 2015). As vessels become bigger and transport large amount of containers, seaports are confronted with the task of accommodating the vessels, and they need to expand the seaport to fulfil the requirement for handling mega vessels (Micheal, 2001). Infrastructure expansion requirements has many aspects that can include transportation, utilities and social, but in the field of maritime transportation, infrastructure is related to the terminals, seaports and equipment (Chandrasekhar, 2009). There are many types of expansion requirements for accommodating mega vessels, and the most important expansion requirement should be identified.

Reviewing the current literature thoroughly is the main technique used to identify the most important expansion that needs to be prioritized by seaport operator to accommodate the current size of mega vessels when they enter the seaport. Identifying process is a form of recognition of the characteristics of social phenomenon clearly explained in detail. Hence, identification process is finding the evidence of the existing problem by describing what is the ideal and factual. Within this research, the identification process requires overall understanding about the expansion requirements that must be met by the seaport to accommodate mega vessels, and the main criteria that need to be considered when expanding certain seaports are seaport navigation, berth operations, terminal operation, yard operation and gate operation. For these main criteria, there are many sub criteria that can be listed through the identification 
process. Through extensive literature review, there are many specific types of seaport expansion requirements, as listed in Table 2 and to be discussed in the next section.

Table 2: Seaport expansion requirements

\begin{tabular}{ll}
\hline \multicolumn{1}{c}{ Main Criteria } & \multicolumn{1}{c}{ Sub-Criteria } \\
\hline Seaport Navigation & Channel Depth, Tug and Pilotage Operation, Nautical Aids \\
Berth Operation & Berth Depths, Mooring Operation, Cranes Operation. \\
Terminal Operation & Bunkering, Stevedoring, Energy and Water Supply \\
Yard Operation & Waste Collection Operations, Yard Operation, Bonded, Equipment and Facilities. \\
Gate Operation & Railway Connection, Road Connection, Custom Clearer. \\
\hline
\end{tabular}

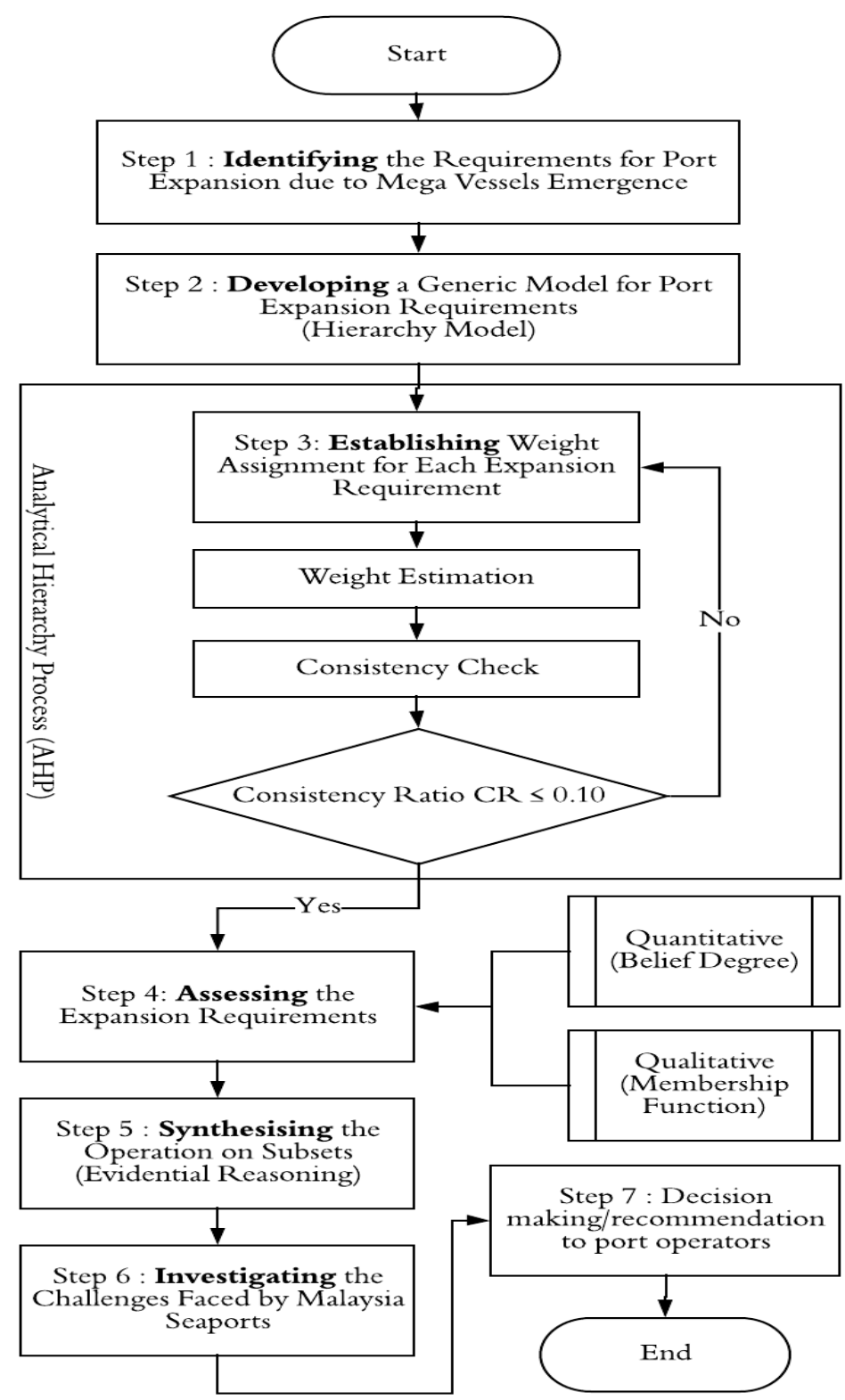

Figure 1: The flowchart of the proposed methodology

\section{Materials and Methods}

In this research, two mathematical methods were used to analyse the data, namely Analytical Hierarchy Process (AHP) and Evidential Reasoning (ER). To identify the expansion requirements that must be met by the seaport due to mega vessels' emergence, a generic model is formed and a combination of different decision-making methods including AHP and ER approaches have been used to quantify the importance of these attributes in 
order to determine the weight vector (Salleh et al., 2015). To develop the calculation process, a flow chart of proposed methodology was designed and is illustrated in Figure 1.

\section{Identification of the expansion requirements for seaports and prioritisation (Steps 1 until 3)}

Step 1 involved identifying the expansion requirements for the seaport, and the literature review was the main technique used to identify the most important expansion that needs to be prioritized by the seaport operator to accommodate the current size of mega vessels when they enter the seaport. Next step was developing a generic model of expansion requirement for the seaport. Then, for Step 3, the AHP method was used to assign a weight to each criterion using pair-wise comparisons. A total of 20 selected experts with more than 10 years of experience in seaport industry were approached to give the best decision and opinion regarding important expansion need that must be met by the seaport to accommodate mega vessels. The criteria used for determining the experts were the following: seaport managers with 10 years of work experience, experts with a degree in maritime study, and senior lecturers involved with maritime studies. To compare the criteria in AHP method approach, each expert should understand the ratio scales of the pair wise comparison before the assessment was taken (Table 3).

Table 3: Comparison scales

\begin{tabular}{cll}
\hline $\begin{array}{c}\text { Intensity of relative } \\
\text { importance }\end{array}$ & \multicolumn{1}{c}{ Definition } & \multicolumn{1}{c}{ Explanation } \\
3 & $\begin{array}{l}\text { Equal importance } \\
\text { Moderate importance of } \\
\text { one over another } \\
\text { Essential or strong } \\
\text { importance }\end{array}$ & $\begin{array}{l}\text { Elements are equally important } \\
\text { Experience and judgment slightly favor }\end{array}$ \\
5 & $\begin{array}{l}\text { Very strong importance } \\
\text { Absolute importance } \\
\text { another } \\
7\end{array}$ & $\begin{array}{l}\text { One is very strongly favored over another } \\
\text { The evidence favoring one over another is of the } \\
\text { higher possible order or affirmation }\end{array}$ \\
$2,4,6,8$ & Intermediate values between two adjacent judgment \\
\hline
\end{tabular}

To quantify judgments of pairs of criterion $A_{i}$ and $A_{j}$ are presented by $n \times n$ matrix $\mathrm{D}$. The $a_{i j}$ entries are defined by entry rules as follows:

- Rule 1: if $a_{i j}=\alpha, 1 / \alpha, \alpha \neq 0$

- Rule 2: if $A_{i}$ is judged to be of equal number of equal relative number as $A_{j}$, then $a_{i j}=a_{j i}=1$.

According to above rules, matrix $\mathrm{D}$ is shown as follows:

$$
\left[\begin{array}{cllc}
1 & a_{n} & \cdots & a_{1 n} \\
1 / a_{n} & 1 & \cdots & a_{2 n} \\
1 / a_{1 n} & 1 / a_{2 n} & \cdots & 1
\end{array}\right]
$$

where $i, j=1,2 \ldots, n$ and each $a_{i j}$ is the relative importance of criterion $A_{i}$ to criterion $A_{j}$.

The quantified judgment of comparison of pair $\left(A_{i}, A_{j}\right)$ is noted as $a_{i j}$ in the matrix D; a further step is to allocate the weight vector for each criterion or alternative, as it shows the prioritization of the criterion or alternatives (Salleh et al., 2015). A weight value $w_{k}$ can be calculated as follows :

$$
w k=\frac{1}{n} \sum_{j=1}^{n}\left(\frac{a k j}{\sum_{j=1}^{n} a_{i j}}\right) k=1,2,3, \ldots, n
$$

where $a_{i j}$ stands for the entry row $i$ and column $j$ in a comparison matrix of order $n$.

By using the Consistency Ratio (CR), inconsistency of the pair wise comparison can be measured. If $C R$ value is 0.10 or less, the consistency of the pair wise comparison can be accepted and considered reasonable, and the AHP can continue with computations of weight vectors (Salleh et al., 2015). In contrast, a CR with greater value than 0.10 indicates an inconsistency in the pair wise judgments. Thus, decision makes review the pair wise judgments before procee check the consistency of the judgments, a CR is computed by using Equations 3-5 (Salleh et al., 2015).

$$
\begin{gathered}
C R=\frac{C I}{R I} \\
C I=\frac{\lambda \max -n}{n-1} \\
\lambda \max =\frac{\sum_{j=1}^{n}\left(\frac{\sum_{k=1}^{n} w k a j k}{w j}\right)}{n}
\end{gathered}
$$

where $\mathrm{CI}$ is the inconsistency index, $\mathrm{RI}$ is the average random index (Table 4), $n$ is the number of items being compared, and $\lambda_{\text {max }}$ is the minimum weight value of the $n \times n$ comparison matrix D (Salleh et al., 2015).

Table 4: Value of Average Random Index

\begin{tabular}{ccccccccccc}
\hline$n$ & $\mathbf{1}$ & $\mathbf{2}$ & $\mathbf{3}$ & $\mathbf{4}$ & $\mathbf{5}$ & $\mathbf{6}$ & $\mathbf{7}$ & $\mathbf{8}$ & $\mathbf{9}$ & $\mathbf{1}$ \\
\hline $\mathrm{RI}$ & 0 & 0 & 058 & 0.9 & 1.12 & 1.24 & 1.32 & 1.41 & 1.45 & $1 .+7$ \\
\hline
\end{tabular}


By using the AHP formula, as shown in Table 5, the result shows that the most important requirement for port expansion is seaport navigation (0.2920), followed by berth operation (0.2867), terminal operation (0.1859), yard operation (0.1327) and gate operation (0.1027).

Table 5: Weightage for each expansion requirement criteria

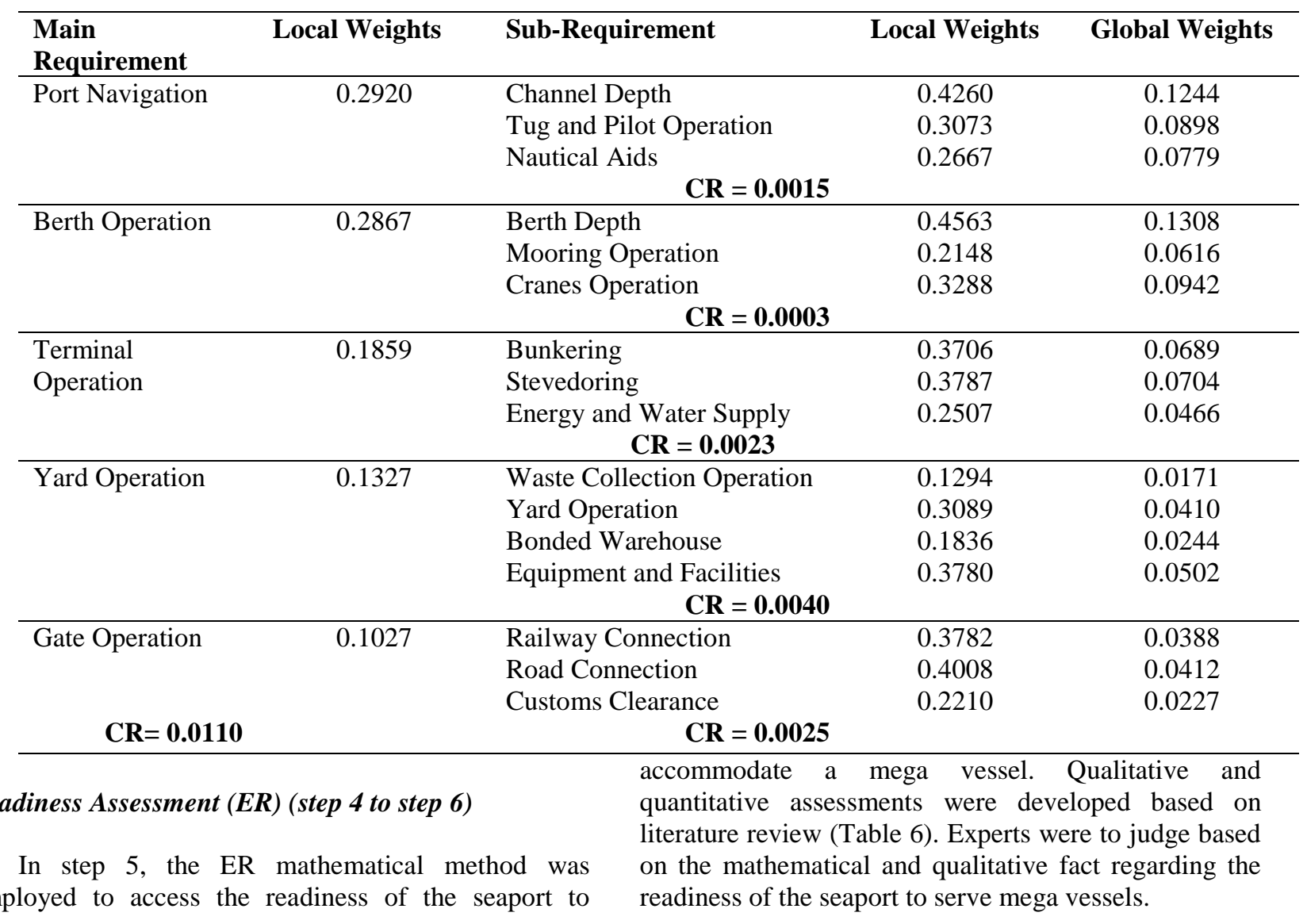

Table 6: Assessment grades for the factors of seaport expansion requirement

\begin{tabular}{|c|c|c|c|c|c|}
\hline \multicolumn{6}{|c|}{ Assessment Grades } \\
\hline $\begin{array}{l}\text { Port Expansion } \\
\text { Requirement }\end{array}$ & Not Ready & Lowly Ready & Fairly Ready & Very Ready & $\begin{array}{c}\text { Absolutely } \\
\text { Ready }\end{array}$ \\
\hline Channel Depth & $\begin{array}{l}\text { Not Ready } \\
\text { (Less than } 5 \mathrm{~m} \\
\text { depths) }\end{array}$ & $\begin{array}{l}\text { Lowly Ready } \\
\text { (6 to } 10 \mathrm{~m} \\
\text { depths) }\end{array}$ & $\begin{array}{l}\text { Fairly Ready } \\
\text { (11 to } 15 \mathrm{~m} \\
\text { depths) }\end{array}$ & $\begin{array}{l}\text { Very Read } \\
\text { (16 to } 19 \mathrm{~m} \\
\text { depths) }\end{array}$ & $\begin{array}{l}\text { Absolutely } \\
\text { Ready } \\
\text { (20m and } \\
\text { above depths) }\end{array}$ \\
\hline $\begin{array}{l}\text { Tug and Pilotage } \\
\text { Operation }\end{array}$ & $\begin{array}{l}\text { Not Ready } \\
\text { (Less than } \\
500 \mathrm{~kW} \text { tugboat } \\
\text { engines for a } \\
\text { maneuvering } \\
\text { mega vessels) }\end{array}$ & $\begin{array}{l}\text { Lowly Ready } \\
(600 \mathrm{~kW} \text { to } \\
1000 \mathrm{~kW} \text { to } \\
\text { maneuvering } \\
\text { mega vessel) }\end{array}$ & $\begin{array}{l}\text { Fairly Ready } \\
(1100 \mathrm{~kW} \text { to } \\
1500 \mathrm{Kw} \text { tug } \\
\text { boat engines for } \\
\text { maneuvering } \\
\text { mega vessels }\end{array}$ & $\begin{array}{l}\text { Very Ready } \\
(1600 \mathrm{~kW} \text { to } \\
2000 \mathrm{~kW} \\
\text { tugboat engines } \\
\text { for maneuvering } \\
\text { mega vessels) }\end{array}$ & $\begin{array}{l}\text { Absolutely } \\
\text { Ready } \\
\text { (2100kW and } \\
\text { above tugboat } \\
\text { engines for } \\
\text { maneuvering a } \\
\text { mega vessels) }\end{array}$ \\
\hline Nautical Aids & Not Ready & Lowly Ready & Fairly Ready & Very Ready & $\begin{array}{l}\text { Absolutely } \\
\text { Ready }\end{array}$ \\
\hline Berth Depth & $\begin{array}{l}\text { Not Ready } \\
\text { (Less than } 5 \mathrm{~m} \\
\text { draft) }\end{array}$ & $\begin{array}{l}\text { Lowly Ready } \\
\text { (6 to } 10 \mathrm{~m} \text { draft) }\end{array}$ & $\begin{array}{l}\text { Fairly Ready } \\
\text { (11 to } 15 \mathrm{~m} \\
\text { draft) }\end{array}$ & $\begin{array}{l}\text { Very Ready } \\
\text { (16 to } 19 \mathrm{~m} \\
\text { draft) }\end{array}$ & $\begin{array}{l}\text { Absolutely } \\
\text { Ready } \\
\text { (20m and } \\
\text { above draft) }\end{array}$ \\
\hline $\begin{array}{l}\text { Mooring } \\
\text { Operation }\end{array}$ & $\begin{array}{l}\text { Not Ready } \\
\text { (Less than } 2 \\
\text { years } \\
\text { experience) }\end{array}$ & $\begin{array}{l}\text { Lowly Ready } \\
\text { ( } 3 \text { to } 5 \text { years } \\
\text { experience) }\end{array}$ & $\begin{array}{l}\text { Fairly Ready } \\
\text { ( } 6 \text { to } 8 \text { years } \\
\text { experience }\end{array}$ & $\begin{array}{l}\text { Very Ready } \\
\text { (9 to } 12 \text { years } \\
\text { experience) }\end{array}$ & $\begin{array}{l}\text { Absolutely } \\
\text { Ready } \\
\text { (More than } 13 \\
\text { years) }\end{array}$ \\
\hline
\end{tabular}




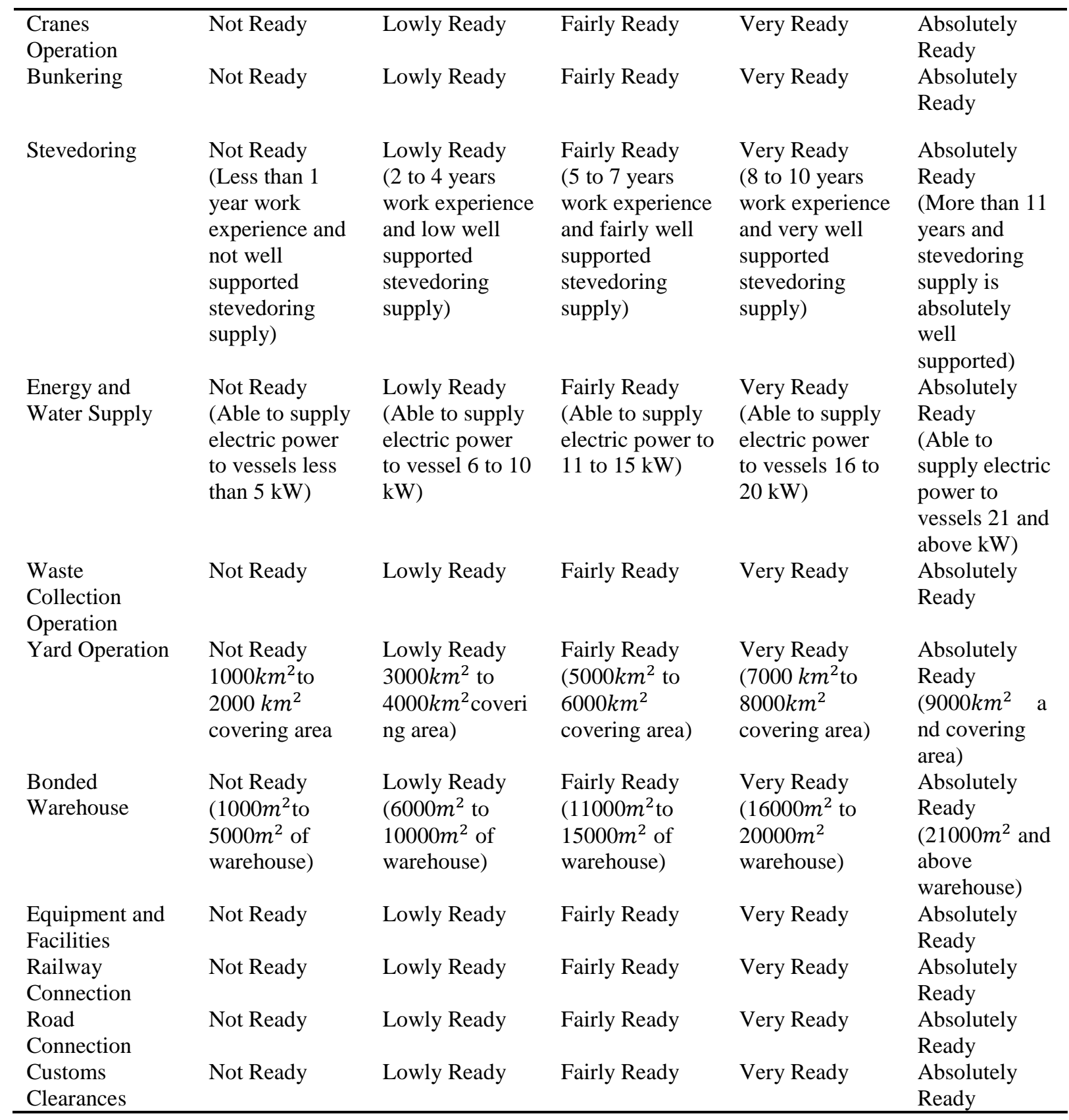

\section{Case study: Northport and Westport at Port Klang}

As the top 20 container seaports in the world, Port Klang is a very suitable to be selected as a case study due to the rapid development and container operation as core business of West Port, one of the seaport operators at Port Klang (West Port, 2017). West Port primarily manages seaport operations dealing in container and conventional cargoes. West port serves as the main gateway for container and conventional cargoes for central region of Peninsular Malaysia. West Port and North Port contribute about $67 \%$ and $33 \%$ of the containers to Port Klang respectively. From the container breakdown in each terminal, $71 \%$ of the containers in West Port are for transhipment and $29 \%$ for import and export, while in North Port about $48 \%$ of the containers are for transhipment and $56 \%$ for import and export (Jeevan et al., 2017). Port Klang, also known as the National Load Centre, plays a crucial role as the main container hub for the regional and economic development of the country. The location of this seaport on the crucial trade lane of Malacca Strait makes Port Klang attractive to many ships on the eastbound leg and the last port of call on the westbound leg of the Far East- Europe trade route (Jeevan et al., 2017). Since the government hubbing strategies that were pursued in 1993, the facilities and services in Port Klang are synonymous with those of a world-class seaport, having trade connections with over 120 countries and more than 500 seaports around the world.

In this test case, an example from one factor was used to prove the result achieved. There were 20 respondents interviewed. After considering the 
respondents' education and their expertise on seaport development and expansion requirements such as navigation, berth terminal, yard and gate operation, these experts were later being classified under the industry, government, private sectors and educational experts. Ministry of Transport (MOT), Port Klang Authority (PKA), Marines Department, and North and West Port is chosen as places to distribute the questionnaires. Questionnaires were provided to help the experts during the interview session. In order to astound the difficulty in assigning weight and avoid prejudgment in the answer, equal weight has been assigned in the questionnaires. Table 7 shows the global weight for lowest level-criteria followed with the ranks. Based on these tables it showed, channel depth is one of the important requirements that need to be prioritized. Next, by using the Evidential Reasoning method the assessment grades toward the readiness of the Port Klang to accommodate a mega vessels are develop. In step 5, all criteria have been assessed (Tables 8 and 9).

Table 7: Ranking orders of the lowest-level criteria

\begin{tabular}{lcc}
\hline Lowest Level Sub- Criteria & Global Weight & Ranks \\
\hline Channel Depth & 0.1244 & 1 \\
Cranes Operation & 0.0942 & 2 \\
Tug and Pilot Operation & 0.0898 & 3 \\
Nautical Aids & 0.0779 & 4 \\
Berth Depths & 0.0779 & 5 \\
Stevedoring & 0.0704 & 6 \\
Bunkering & 0.0689 & 7 \\
Mooring Operation & 0.0616 & 8 \\
Equipment and Facilities & 0.0502 & 9 \\
Energy and Water Supply & 0.0466 & 10 \\
Road Connection & 0.0412 & 11 \\
Yard Operations & 0.0410 & 12 \\
Railway Connection & 0.0388 & 13 \\
Bonded Warehouse & 0.0244 & 14 \\
Customs Clearance & 0.0227 & 15 \\
Waste Collection Operation & 0.0171 & 16 \\
\hline
\end{tabular}


Table 8: Assessment outcomes for the expansion requirements

\begin{tabular}{lcccccc}
\hline Requirements & & \multicolumn{2}{c}{ Readiness Scales } & \multirow{2}{*}{ Weight } \\
\cline { 1 - 5 } Seaport Navigation & Not Ready & Lowly & Fairly & Very & Absolutely & \\
& & Ready & Ready & Ready & Ready & \\
\hline Channel Depth & 0 & 0 & 0.0309 & 0.9691 & 0 & 0.4260 \\
Tug and Pilotage Operation & 0 & 0 & 0.0665 & 0.9335 & 0 & 0.3074 \\
Nautical Aids & 0 & 0 & 0.3132 & 0.6868 & 0 & 0.2667 \\
Aggregation Result & 0 & 0 & 0.0998 & 0.9002 & 0 & 1.0000 \\
Berth Operation & Not Ready & Lowly & Fairly & Very & Absolutely & Weight \\
& & Ready & Ready & Ready & Ready & \\
Berth Depth & 0 & 0 & 0 & 0.9687 & 0.0313 & 0.4563 \\
Mooring Operation & 0 & 0 & 0.0696 & 0.8965 & 0.0339 & 0.2148 \\
Cranes Operation & 0 & 0 & 0.0726 & 0.8548 & 0.0726 & 0.3288 \\
Aggregation Result & $\mathbf{0}$ & $\mathbf{0}$ & $\mathbf{0 . 0 3 2 7}$ & $\mathbf{0 . 9 3 5 5}$ & $\mathbf{0 . 0 3 1 8}$ & $\mathbf{1 . 0 0 0 0}$ \\
& & & & & & \\
Terminal Operation & Not Ready & Lowly & Fairly & Very & Absolutely & Weight \\
& & Ready & Ready & Ready & Ready & \\
Bunkering & 0 & 0 & 0.0309 & 0.9691 & 0 & 0.3706 \\
Stevedoring & 0 & 0 & 0.0665 & 0.9335 & 0 & 0.3787 \\
Energy and Water Supply & 0 & 0 & 0.1068 & 0.8932 & 0 & 0.2507 \\
Aggregation Result & $\mathbf{0}$ & $\mathbf{0}$ & $\mathbf{0 . 0 5 5 7}$ & $\mathbf{0 . 9 4 4 3}$ & $\mathbf{0}$ & $\mathbf{1 . 0 0 0 0}$ \\
Yard Operation & Not Ready & Lowly & Fairly & Very & Absolutely & Weight \\
& & Ready & Ready & Ready & Ready & \\
Waste Collection Operation & 0 & 0 & 0.1643 & 0.7578 & 0.0779 & 0.1294 \\
Yard Operation & 0 & 0 & 0.3736 & 0.6264 & 0 & 0.3089 \\
Bonded Warehouse & 0 & 0 & 0.5637 & 0.4363 & 0 & 0.1836 \\
Equipment and Facilities & 0 & 0 & 0.5000 & 0.5000 & 0 & 0.3781 \\
Aggregation Result & $\mathbf{0}$ & $\mathbf{0}$ & $\mathbf{0 . 3 8 0 2}$ & $\mathbf{0 . 6 0 4 4}$ & $\mathbf{0 . 0 1 5 3}$ & $\mathbf{1 . 0 0 0 0}$ \\
Gate Operation & Not Ready & Lowly & Fairly & Very & Absolutely & Weight \\
Railway Connection & & Ready & Ready & Ready & Ready & \\
Road Connection & 0 & 0 & 0.4363 & 0.5637 & 0 & 0.3782 \\
Customs Clearances & 0 & 0 & 0.2015 & 0.7985 & 0 & 0.4008 \\
Aggregation Result & 0 & 0 & 0.0779 & 0.7578 & 0.1643 & 0.2210 \\
\cline { 1 - 3 } & $\mathbf{0}$ & $\mathbf{0}$ & $\mathbf{0 . 2 0 1 7}$ & $\mathbf{0 . 7 5 6 1}$ & $\mathbf{0 . 0 4 2 2}$ & $\mathbf{1 . 0 0 0 0}$ \\
\hline
\end{tabular}

Table 9: Assessment outcomes for the main requirements

\begin{tabular}{lcccccc}
\hline Main Criteria & Not Ready & $\begin{array}{l}\text { Lowly } \\
\text { Ready }\end{array}$ & $\begin{array}{l}\text { Fairly } \\
\text { Ready }\end{array}$ & $\begin{array}{l}\text { Very } \\
\text { Ready }\end{array}$ & $\begin{array}{l}\text { Absolutely } \\
\text { Ready }\end{array}$ & $\begin{array}{l}\text { Utility } \\
\text { Value }\end{array}$ \\
\hline Seaport Navigation & 0 & 0 & 0.0998 & 0.9002 & 0 & 0.7250 \\
Berth Operations & 0 & 0 & 0.0327 & 0.9355 & 0.0315 & 0.7498 \\
Terminal Operation & 0 & 0 & 0.0557 & 0.9443 & 0 & 0.7361 \\
Yard Operation & 0 & 0 & 0.3802 & 0.6044 & 0.0153 & 0.6588 \\
Gate Operation & 0 & 0 & 0.2017 & 0.7561 & 0.0422 & 0.7101 \\
Aggregation & $\mathbf{0}$ & $\mathbf{0}$ & $\mathbf{0 . 0 8 5 3}$ & $\mathbf{0 . 9 0 3 4}$ & $\mathbf{0 . 0 1 1 3}$ & $\mathbf{0 . 7 3 1 5}$ \\
\hline
\end{tabular}




\section{Results and Discussion}

Outcomes of the assessment indicate that the emergence of mega vessels requires Port Klang to make a massive development in term of infrastructure and operation requirements. The AHP was tested with $\mathrm{CR}$ to prove the validity of collected data. CR values are shown in Table 5 accordingly. To validate data, $\mathrm{CR}$ value must be less than or equal to 0.10 . In this study, CR for main criteria was 0.0110 , while for the sub criteria seaport navigation (0.0015), berth operation (0.0003), terminal operation $(0.0023)$, yard operation $(0.0040)$ and gate operation (0.0025). In a nut shell, these collected data were valid. By using the IDS software, the overall utility value for the readiness level based on the entire requirement and the expert judgment was $73.15 \%$ (Table 9). As Malaysia mega hub seaport and focal distribution centre, Port Klang is considered $73.15 \%$ ready to accommodate mega vessels with their current requirements.

Based on the outcomes of this research, a few challenges have been identified, such as quay cranes and yard productivity, requirement of additional yard space, utilization issues on quay crane and rampant increments on operation cost, that the seaport needs to overcome to accommodate mega vessels. The rapid increase in the size of mega vessels already have caused some issues for many seaports with regards to quay cranes and yard productivity. Current mega vessels tend to have higher draft. The design of the quay crane walls takes vessel draft as the most important element to determine the required holding of quay. If the vessel size increases, higher quay walls will be required for vessels to call without harm. It can be probable that for a 20,250 TEU vessel the retaining height needed is 25.85 meter (UNCTAD, 2014), which importantly is more than what is available at a great number of seaport terminals in the world. In term of yard productivity, there is a clear link between dwell times in container yard with vessel size. There are two possibilities to solve peak in yard caused by large capacity of container arrivals at the seaport, which are increasing the yard density and reducing dwelling time. The consensus among mega vessels is terminal should accommodate mega vessels in one day and they need to improve productivity to sustain the seaport competitive advantages. Another challenge faced by the seaport operators is the low quay utilization. Utilization in seaports is very crucial especially on berth utilization. Since berth is the main asset of seaports, it is important to measure the performance of the berths in term of the throughput handled per berth to ensure continuous productivity.

\section{Conclusion}

This study is expected to assist seaport operators in prioritising the requirements for seaports in making infrastructure expansion. Using two mathematical methods, which are AHP and ER, can guide the policy makers, seaport operators as well as seaport authorities in overcoming the changes in the vessel size. This study offers clear measurement on the readiness of seaports to serve mega vessels in global shipping industry to achieve optimum level of competitiveness. In order to become superior in this dynamic business, seaports must produce good services to the customers. Therefore, competitive advantages are attributed to a variety of factors including cost structure, quality of services and productivity, the distribution network as well as efficiency in customer services. Seaports must modernise their cargo handling process and modify container facilities to improve inbound and outbound cargo flow due to the changes in the vessel size.

\section{Acknowledgement}

My appreciation goes to the School of Maritime Business and Management, Universiti Malaysia Terengganu for the financial and facility supports.

\section{References}

Chandrasekhar, M. (2009). Port Infrastructure Development Opportunities in these Challenging Times. AAPA Commission Seminar Boston May 20th, 2009.

European Community Ship-owner Association. (2016). Short Sea Shipping the Potential yet to be Unleashed. Amsterdam Niels Smedegaard, ECSA President. Retrieved from http://www.shortsea.fr/sites/default/files/fichiers/pu blic/2016-02-

15_short_sea_shipping_niels_smedegaard_amsterd am.pdf, 8 December 2018.

Jeevan, J., Ghaderi, H., Bandara, Y. M., Saharuddin, A. H., \& Othman, M. R. (2015). The Implications of the Growth of Port Throughput on the Port Capacity: the Case of Malaysian Major Container Seaports. International Journal of E-Navigation and Maritime Economy, 3, 84-98. https://doi.org/10.1016/j.enavi.2015.12.008.

Jeon, J. W., \& Yeo, G. T. (2017). Study of the Optimal Timing of Container Ship Orders Considering the Uncertain Shipping Environment. Asian Journal of Shipping and Logistics, 33(2), 85-93. https://doi.org/10.1016/j.ajs1.2017.06.006.

Merk, O. (2016). The Impact of Alliances in Container Shipping, Economist, Ports and Shipping. International Transport Forum. Retrieved from https://2016.itf- oecd.org/merk, 22 February 2018.

Micheal, C. I. (2001). Serving tomorrow's Mega Size Container Ships the Canadian Solution. International Journal of Maritime Economics, Vol. 3, 2001, 318-332. 
Organization for Economic Co-operation and Development. (2017). The Impact of Mega Ships, The International Transport Forum. Retrieved from https://www.itfoecd.org/sites/default/files/docs/15cspa_megaships.pdf, 22 February 2018.

Pinder, T. B. (2016). The Impact of Mega-Ships and Carrier Alliances on Ports and Terminals. PhD theses, California State University, Maritime Academy.

Port Technology International. (2015). Mega-ships create port upgrade race. Retrieved from, https://www.porttechnology.org/news/mega_ships create port upgrade race, 22 February 2018.

Rodrigues, J. P. (2017).Evolution of Containership. Published online at The Geography of Transport System. Retrieved from https://transportgeography.org/?page_id=2232, $22 \quad$ February 2018.

Salleh, N., Riahi, R., Yang, Z., \& Wang, J. (2014). Risk Assessment of Liner Shipping from a Business Environment Perspective (ASCE). Second International Conference on Vulnerability and Risk Analysis and Management (ICVRAM) and the Sixth International Symposium on Uncertainty, Modeling, and Analysis (ISUMA). Retrieved from https://ascelibrary.org/doi/10.1061/9780784413609. $\underline{233}, 22$ February 2018.

United Nation Conference on Trade and Development.(2014). Review of Maritime Transport, United Nation Publication. Retrieved from https://unctad.org/en/PublicationsLibrary/rmt2014_ en.pdf, 22 February 2018.

United Nation Conference on Trade and Development.(2017). Review of Maritime Transport, United Nation Publication. Retrieved from https://unctad.org/en/PublicationsLibrary/rmt2017_e n.pdf, 22 February 2018.

Wang, Y.M., Yang, J.B. \& Xu, D.L. (2006). Environmental impact assessment using the evidential reasoning approach. European Journal of Operational Research, 174(3), 18851913.

West Port (2017). Annual Report 2017. Westport Holding Berhad. Retrieved from http://ir.chartnexus.com/westportsholdings/docs/ar2 017.pdf, 22 February 2018.

Yoe, H. (2015). Participation of Private Investors in Container Operation: Influences of Global Terminal Operators. The Asian Journal of Shipping and Logistics, 363-38. 